\title{
Immunotherapy - 2082. Long term prevention of asthma and rhinitis in children with atopic dermatitis four year after discontinuation of sublingual immunotherapy
}

\author{
Giovanni Passalacqua ${ }^{1 *}$, Valentina Garelli ${ }^{1}$, Francesca Sclifó ${ }^{1}$, G Walter Canonica ${ }^{1}$, Giovanni Pajno ${ }^{2}$ \\ From 2nd WAO International Scientific Conference (WISC 2012) \\ Hyderabad, India. 6-9 December 2012
}

\section{Background}

Atopic Dermatitis is a disease with high prevalence in Italy (about 15\% of the population). As known, Atopic Dermatitis is often associated with respiratory allergy to mite.We previously showed that sublingual immunotherapy (SLIT) to mite has a beneficial clinical effect in patients with allergic extrinsic Atopic Dermatititis (AD). To investigate the long term effects, we performed a 4-year follow up after the termination of SLIT.

\section{Methods}

46 children with $\mathrm{AD}$, aged 5-16 years and allergic to mite were re-assessed 4 years after discontinuation of a 2-year course of SLIT (or placebo). Methacholine provocation tests were carried out at baseline, after 2 years (when SLIT was stopped) and after 4 years. The development of asthma and rhinitis was assessed by clinical evaluations.

\section{Results}

The children who previously had received SLIT had significantly less asthma after 6 years as evaluated by clinical symptoms: odd ratio $3.73(0.130$ vs $0.511 ; \mathrm{P}=0.02)$ as compared to the former placebo group. In addition, significantly less patients reported an increase in asthma scores $\mathrm{P}=0.003$. A significant difference in bronchial methacholine responsiveness was found between the two groups $(\mathrm{P}=0.03)$, with an overall lower bronchial hyperreactivity in children who previously received active SLIT.

Dept of Internal Medicine, Genoa University Allergy and Respiratory Diseases, Genova, Italy

Full list of author information is available at the end of the article

\section{Conclusions}

A 2-year course of SLIT to mite provided a long term clinical effect and prevented the development of asthma in children with allergic extrinsic form of Atopic Dermatitis.

\section{Author details}

'Dept of Internal Medicine, Genoa University Allergy and Respiratory Diseases, Genova, Italy. ${ }^{2}$ Dept of Pediatrics, Allergy Unit, University of Messina, Messina, Italy.

Published: 23 April 2013

\section{doi:10.1186/1939-4551-6-S1-P163}

Cite this article as: Passalacqua et al:: Immunotherapy - 2082. Long term prevention of asthma and rhinitis in children with atopic

dermatitis four year after discontinuation of sublingual immunotherapy. World Allergy Organization Journal 2013 6(Suppl 1):P163.

Submit your next manuscript to BioMed Central and take full advantage of:

- Convenient online submission

- Thorough peer review

- No space constraints or color figure charges

- Immediate publication on acceptance

- Inclusion in PubMed, CAS, Scopus and Google Scholar

- Research which is freely available for redistribution 